\section{Commentary: What's old is new again: Atrial baffle for complex cardiac transplantation}

\author{
Roosevelt Bryant III, MD
}

The history of surgical repair of transposition of the great vessels is replete with innovative palliative surgical procedures, including the Blalock-Hanlon atrial septectomy ${ }^{1}$ and the Rashkind balloon atrial septostomy. ${ }^{2}$ The era of surgical correction began with a number of procedures aimed at physiologic repair, including the Baffes operation described by Dr Lillehei. ${ }^{3}$ These so-called atrial switch procedures redirect the systemic venous return to the left ventricle and the pulmonary venous return to the right ventricle. The 2 most commonly applied techniques used autologous atrial and septal flaps (Senning procedure) ${ }^{4}$ or a pericardial baffle (Mustard procedure $)^{5}$ to achieve rerouting of the pulmonary and systemic venous return. In this issue of JTCVS techniques, Nakamura and colleagues ${ }^{6}$ use a technique similar to the Mustard atrial baffle to achieve levocardia heart transplantation in a patient with complex single-ventricle congenital heart disease. The anatomic obstacles the authors had to overcome included dextrocardia, a common atrium, and a left-sided inferior vena cava and superior vena cava.

In their report, a pericardial baffle was used to septate a common atrium and re-route the right-sided pulmonary venous return to a common left-sided orifice with the left pulmonary veins. This approach for managing atrial septation has been well described by Huddleston and others for patients with situs inversus totalis. ${ }^{7}$ There are 2 particular points of emphasis from the Huddleston technique that

\footnotetext{
From the Division of Congenital Heart Surgery, The Heart Center, Phoenix Children's Hospital, Phoenix, Ariz.

Disclosures: The author reported no conflicts of interest.

The Journal policy requires editors and reviewers to disclose conflicts of interest and to decline handling or reviewing manuscripts for which they may have a conflict of interest. The editors and reviewers of this article have no conflicts of interest.

Received for publication May 24, 2021; revisions received May 24, 2021; accepted for publication June 1, 2021; available ahead of print June 12, 2021.

Address for reprints: Roosevelt Bryant III, MD, Department of Child Health, The University of Arizona College of Medicine-Phoenix, Heart Transplantation and Mechanical Circulatory Support, Phoenix Children's Hospital, 1919 E Thomas Rd, Phoenix, AZ 85016 (E-mail: rbryant1@phoenixchildrens.com). JTCVS Techniques 2021;8:192-3

2666-2507

Copyright (C) 2021 The Author(s). Published by Elsevier Inc. on behalf of The American Association for Thoracic Surgery. This is an open access article under the CC BY-NC-ND license (http://creativecommons.org/licenses/by-nc-nd/4.0/). https://doi.org/10.1016/j.xjtc.2021.06.004
}

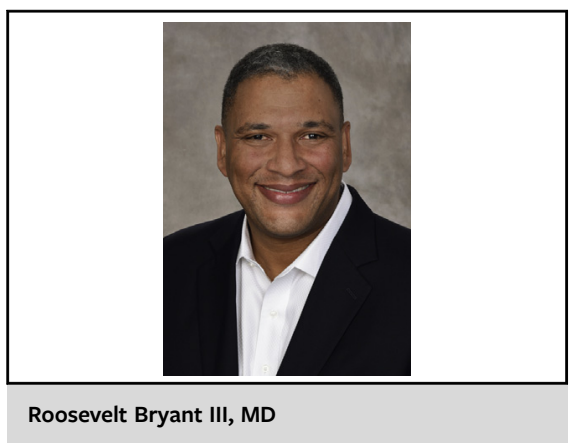

CENTRAL MESSAGE

An atrial baffle technique can be used to achieve levocardia heart transplantation in patients with complex single ventricle congenital heart disease with dextrocardia and a common atrium

readers should keep in mind for the current report. These are demonstrated in the Figure 1. First, resection of the atrial wall (left panel, Figure 1) between the left and right pulmonary venous ostia is important to provide an unobstructed pulmonary venous pathway, particularly from the right pulmonary veins. Second, creation of a large opening in the left interatrial groove (right panel, Figure 1) for anastomosis to the left atrium of the donor organ is an important technical modification that will also limit the potential for pulmonary venous pathway obstruction. While there are similar elements to the Mustard atrial baffle for transposition, this technique of atrial rerouting of the systemic and venous return has clear distinctions from that procedure. The most obvious distinguishing feature is that the Nakamura baffle procedure resulted in a systemic left ventricle unlike the physiologic correction of transposition, whereas the Mustard procedure leaves the patient with a systemic right ventricle. Second, in the report by Nakamura and colleagues, the patient had a common atrium unlike most patients with complete transposition of the great vessels. The drawbacks of the atrial baffle procedure remain. Specifically, the surgeon must ensure a technical result that limits the potential for systemic and pulmonary venous outflow obstruction. The application of time-honored surgical techniques to emerging clinical problems emphasizes the need to remain vigilant in our knowledge and understanding of surgical history because what is old may become new again. 

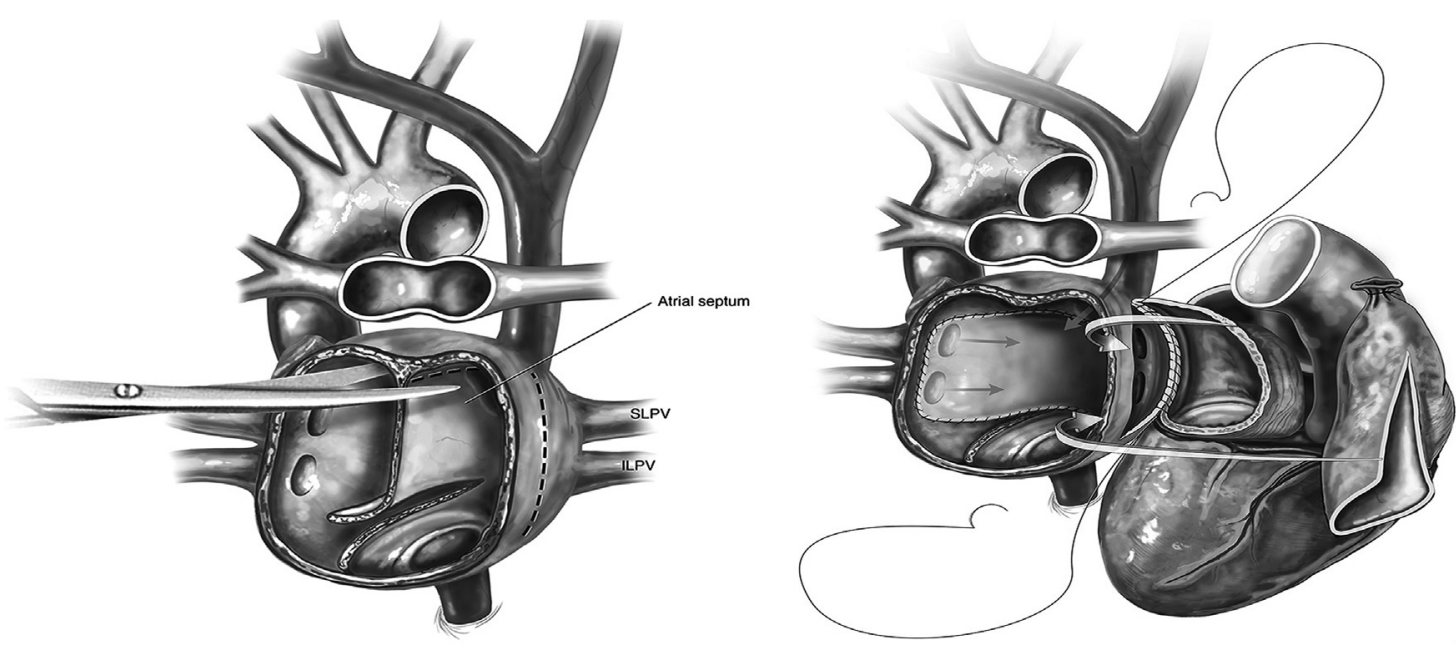

FIGURE 1. Left panel: Resection (scissors) of atrial septum between the right and left pulmonary venous ostia. Right panel: Creation of pericardial atrial baffle to septate the systemic and pulmonary venous return. A large incision is made is in the left interatrial groove for anastomosis to the left atrium of the donor organ (pictured) using a biatrial implant technique. (From Huddleston and colleagues. ${ }^{7}$ )

\section{References}

1. Blalock A, Hanlon CR. The surgical treatment of complete transposition of the aorta and the pulmonary artery. Surg Gynecol Obstet. 1950;90:1.

2. Rashkind WJ, Miller WW. Creation of an atrial septal defect without thoracotomy: a palliative approach to complete transposition of the great arteries. JAMA. 1966; 196:991.

3. Baffes TG. A new method for surgical correction of transposition of the aorta and pulmonary artery. Surg Gynecol Obstet. 1956;102:227.
4. Senning A. Surgical correction of transposition of the great vessels. Surgery. 1959; 45:966.

5. Mustard WT. Successful two-stage correction of transposition of the great vessels Surgery. 1964;55:469.

6. Nakamura Y, Ayoubi A, Ashwath R, Exil V, Ricci M. An atrial switch procedure for heart transplantation in an infant with heterotaxy-dextrocardia. J Thorac Cardiovasc Surg Tech. 2021;8:189-91.

7. Huddleston CB, Richey S, Fiore AC. Heart transplantation for congenital heart disease. Oper Tech Thorac Cardiovasc Surg. 2019;24:103-20. 